\title{
FINANCIAL STRATEGY FOR ESTABLISHING LEASING COMPANY
}

\author{
Bulatova E.I. \\ $\mathrm{PhD}$ in Economics, Banking Department of the Institute of \\ Management, Economy and Finance, \\ Kazan Federal University \\ Kazan, Russian Federation \\ bulatovaei@yandex.ru

\section{Syurkova S.M.} \\ $\mathrm{PhD}$ in Economics, Finance Department \\ of the University of Management "TISBI" \\ Kazan, Russian Federation \\ syurkova@mail.ru
}

\author{
Aliakberova L.Z. \\ Associate Professor of the Chair of Islamic Economy and \\ Management, Russian Islamic Institute, \\ Kazan, Russian Federation \\ lilya67@mail.ru
}

\begin{abstract}
The article deals with the research results of the feasibility of implementing recommendations and suggestions towards developing a financial strategy for creating a leasing company.
\end{abstract}

Keywords- financial strategy, leasing company, leasing product, ijara

\section{INTRODUCTION}

The increasing complexity of market mechanisms and their diversity, intensity of economic and commercial processes force businesses to utilize all the resources and capabilities fully. In this regard, it is very important to have a clear definition of the company's financial strategy, to research thoroughly the economic nature, principles and the main components of the strategy, including the stages and levels of its implementation [1].

The key stages of developing the enterprise's financial strategy are as follows [2]:

- calculations of the strategy's implementation period;

- analysis of the company's external financial environment factors, study of economic and legal conditions of the company's activity and other risks;

- formation of the strategic objectives of the financial activity;

- development of the company's financial policy;

- development of the set of measures on the financial strategy implementation;

- developed financial strategy assessment.

The priorities of financial performance include profit maximization of the enterprise, optimization of the company's capital structure and provision for its investment attractiveness and enhancement of the company's market value $[3,4]$.

The significance of the topic is also defined by fact that the issues of development and realization of the company's financial strategy, including the leasing one, considering current financial crisis, require new theoretical, methodological and scientific research [5]. Thus, for example, further in-depth study should be targeted at the issues of the companies' activities sustainability increase [6], risk assessment and management in current crisis environment [7].

\section{RESULTS}

With the aim of forming the financial strategy for creating leasing company, an analysis has been developed on characteristics of leasing services growth in Russia, which showed the following outcomes:

- leasing companies' activities are expanding through new branches and assets, terms of lease agreements are boosting, financial conditions become more favorable for lessees [8];

- in 2016, the leasing market, being one of the indicators of investment activity in economy, demonstrated negative dynamics;

- among the top three segments of the leasing market (namely, air lease, car lease and railroad lease), only car lease gained 28.4 percent;

- with a view to maintain customer demand for leasing services, lessors began to take frequent part in different state programs, aimed at lessees' support by subsidizing leasing or renting of specific assets [9]; 
- leasing market is expected to reduce the decline in 2017, but it will continue to shrink, following the dynamics of the investments in fixed capital (in 2016, the drop of the investments in capital made up 5.3 percent (in $2015-8.4 \%$, in $2014-1.5 \%$ ); and in accordance with the results of 2017 , the drop will make not less than 3-4\%) [10].

On the bases of the Ministry of Economic Development of RF projection about Russia's GDP of RUR equal to 153.6 trillion in 2020, it is possible to assess an anticipated leasing sector in Russian economy under various scenarios realization (Table 1) [11].

TABLE 1. FORECAST OF THE LEASING MARKETS' VOLUMES UNDER VARIOUS SCENARIOS REALIZATION

\begin{tabular}{|c|c|c|c|c|c|c|}
\hline Period & \multicolumn{2}{|c|}{$\begin{array}{c}\text { Pessimistic } \\
\text { scenario }\end{array}$} & \multicolumn{2}{c|}{ Neutral scenario } & \multicolumn{2}{|c|}{$\begin{array}{c}\text { Optimistic } \\
\text { scenario }\end{array}$} \\
\cline { 2 - 7 } & $\begin{array}{c}\text { Growth } \\
\text { rates } \\
\text { per } \\
\text { year, \% }\end{array}$ & $\begin{array}{c}\text { Market } \\
\text { volume, } \\
\text { bln. } \\
\text { rubles. }\end{array}$ & $\begin{array}{c}\text { Growth } \\
\text { rates } \\
\text { per } \\
\text { year, \% }\end{array}$ & $\begin{array}{c}\text { Market } \\
\text { volume, } \\
\text { bln. } \\
\text { rubles. }\end{array}$ & $\begin{array}{c}\text { Growth } \\
\text { rates per } \\
\text { year, \% }\end{array}$ & $\begin{array}{c}\text { Market } \\
\text { volume, } \\
\text { bln. } \\
\text { rubles. }\end{array}$ \\
\hline 2016 & 15 & 3741 & 18 & 6281 & 20 & 10091 \\
\hline 2017 & 15 & 4302 & 18 & 7411 & 20 & 12109 \\
\hline 2018 & 15 & 4948 & 20 & 8894 & 25 & 15136 \\
\hline 2019 & 20 & 5937 & 25 & 11117 & 30 & 19677 \\
\hline 2020 & 20 & 7125 & 25 & 13896 & 30 & 25581 \\
\hline $\begin{array}{c}\text { GDP's } \\
\text { leasing } \\
\text { share in } \\
2020, \%\end{array}$ & - & $4.6 \%$ & - & $9 \%$ & - & $16.6 \%$ \\
\hline A & & & & & & \\
\hline
\end{tabular}

A promising trend of leasing market nowadays comprises the use of leasing products by Islamic type.

According to AAOIFI international standards, ijara means operating lease, under which some institution acquires and leases out an equipment for rent. The agreement is not subject to promise that the leased property will be transferred to the lessee at the expiry of the lease period.

Ijara instrument is equivalent to leasing in the conventional financial system. The main criteria for comparing terms of transactions under ordinary leasing and ijara leasing are shown in Table 2 [13].

TABLE 2. CRITERIA FOR COMPARING TERMS OF TRANSACTIONS UNDER ORDINARY LEASING AND IJARA LEASING

\begin{tabular}{|l|l|}
\hline Leasing transactions criteria & \multicolumn{1}{|c|}{ Ijara transactions criteria } \\
\hline Property & Early termination of the contract \\
\hline Risk bearer & Service pay \\
\hline Profit & Updates \\
\hline Full implementation & Change in rent prices \\
\hline Delayed rent payment recovery & Advance payment \\
\hline Insurance coverage & $\begin{array}{l}\text { Influence of long-term termination of } \\
\text { partnership }\end{array}$ \\
\hline Funding & $\begin{array}{l}\text { Sales and reverse leasing as one } \\
\text { transaction }\end{array}$ \\
\hline Terms & Rent prices identifier \\
\hline Obligations of the lessee & Sales equivalent \\
\hline $\begin{array}{l}\text { Evaluation at the end of lease } \\
\text { period }\end{array}$ & \\
\hline
\end{tabular}

Leasing payments under ijara model include compensation of the lessor's expenses, connected with acquisition and transfer of the ijara item to the leaseholder, other services delivery stipulated by the agreement, and the lessor's profit.

Apart from other participants of lease transactions, as part of the ijara mechanism, there is an additional person called a service agent, who is to assume particular scope of rights and duties of the lessor, which are usually assumed by the lessee in common practice of the financial strategy.

According to the principles of Islamic rights, the core obligations relating to insurance or repair of the lease property are the responsibilities of the lessor [12]. The same applies to the lease registration responsibilities or receiving permission for the use of the equipment or the leased item, as far as they relate to the lease maintenance. Those responsibilities cannot be delegated to the lessee under ijara agreement without violations of Sharia principles. In order to adapt those principles to conventional market conditions, within ijara transaction, additional documents are to be established, through which the lessee (or other person according to the lessee's contract) assumes the responsibilities from the lessor, but this time, as a service agent or a debtor, depending on a specific structure of transaction.

Apart from the leasing agreement (ijara) and security documentation, additional instruments are introduced:

- $\quad$ sales contract (revised or assigned);

- bill of sale;

- leasing agreement (ijara);

- agency agreement;

- purchase obligation;

- sale obligation;

- replacement obligation;

- substitution obligation;

- warranty/provision;

- other documents (documents of the agency for investments or Sukuk).

Not only in Russia, but everywhere in the world there is a growing interest towards ijara. In the context of the complex and difficult situation on the Russian market, the investors' attention should not be expected. The objective obstacles of traditional fund raising for the Russian market participants, together with increasing investors' interest towards new to Islamic financing markets, create preconditions for accelerated utilization of ijara instruments on the Russian market.

The concept of a new leasing company consists of promoting a new leasing ijara product on the Russian market, meeting all the requirements of Russian legislation and Sharia principles.

The main preconditions for a company creation are as 
follows:

- geography: the company will be established in Kazan city, which is one of the major business and economic centres of the Republic of Tatarstan and Russia;

- attractiveness of the market of leasing services: current tendencies on the regional market of automotive industry and in the area of leasing services, though reveal a decreasing trend, have favourable prospects;

- development of infrastructure of Islamic finance and banking: Tatarstan is experienced in creating companies on principles of Islamic economy;

- attractiveness of the market and product: ijara product is promising for the regional market;

- competitive environment of the project on the regional market: in Tatarstan, the Eurasian Leasing Company functions, which offers a wide range of services based on the Islamic model.

Within the project's scope, B category automobiles and trucks serve the subjects of the lease. To generate a forecast of leasing transactions, standard transactions for vehicles leasing are provided (Table 3.) [14].

TABLE 3. STANDARD TRANSACTIONS FOR VEHICLES LEASING

\begin{tabular}{|l|c|c|c|}
\hline \multicolumn{1}{|c|}{ Name } & $\begin{array}{c}\text { Average cost of the } \\
\text { leased items }\end{array}$ & $\begin{array}{c}\text { Amount of } \\
\text { advance } \\
\text { payment }\end{array}$ & Leasing term \\
\hline $\begin{array}{l}\text { B category } \\
\text { automobiles }\end{array}$ & RUR 2 000 thousand & $20-50 \%$ & 24 months \\
\hline Trucks & RUR 2 500 thousand & $20-50 \%$ & 24 months \\
\hline
\end{tabular}

It is planned to make the focus on B category automobiles when implementing a leasing company services, which is attributable to a better liquidity of this kind of vehicles if the lease is not paid (Fig, 1.).

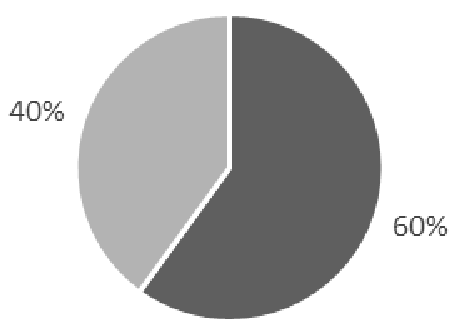

- B category automobiles = Trucks

Fig. 1. Planning structure of lease portfolio, as a percentage

The project timetable is stipulated from January 2017 (technical preparation) up to 2018 (access to intended conclusion of contracts within the project).
The investment costs of the project are composed from expenditures, necessary for launching a leasing company and make up RUR 828 thousand. Funding sources for investment costs on the project are internal resources.

The project implies growth of leasing transactions during the first two years of the project's realization. In the years ahead, sales volumes are expected to remain stable at the second year level.

The leasing company's income is composed of the lessor's advance payments, the amount of leasing payment from leasing transactions, agent's remuneration from insurance companies, when insuring trucks and B category automobiles.

The source of funding leasing transactions within the project is bank financing. The credit funds will be raised for every transaction through open credit in the bank. 4.

The key indicators of the project are summarized in Table

TABLE 4. THE PROJECT PERFORMANCE INDICATORS

\begin{tabular}{|l|c|c|}
\hline \multicolumn{1}{|c|}{ Performance indicator } & Designation & Value \\
\hline Net present value (RUR) & NPV & 53762 \\
\hline Modified IRR (of cost effectiveness) & IRR & $22.2 \%$ \\
\hline Discount rate & D & $11.2 \%$ \\
\hline
\end{tabular}

According to calculations, the project is effective. It is evidenced by the positive net present value.

\section{PROJECT IMPLEMENTATION RISKS}

Financial risks management as a whole and credit risk management particularly for leasing company are one of the main functions of risk management, which is aimed at reduction of risks and total cost of financing, accordingly. Leasing company's major credit risks can be divided into leasing project risks and portfolio risks of leasing projects.

Components of leasing company credit risk have the following classification:

1. According to the object, namely the risk holder:

- leasing projects individual risks;

- client's company individual risks;

- leasing portfolio risks;

- group of clients risks (industry, regional);

- leasing property risks (withdrawal, death or damage to property, identification, accelerated moral or physical amortization, subsequent implementation, etc.).

2. According to the procedure of leasing projects approval:

- risks of projects, approved on the basis of complete analysis;

- risks of projects, approved on the basis of simplified analysis and scoring models.

3. According to the project's typicality for the company: 
- typical projects risks (typical risks);

- analogous projects risks;

- innovative projects risks (new risks for the company).

4. According to the stage of leasing transaction:

- risks of the preparation stage and leasing transaction;

- transaction stage risks;

- avoidance proceeding risks.

5. According to risks commonality:

- risks events;

- unifying (aggregate) risks.

6. According to damage size:

- minor;

- significant;

- inappropriate.

7. According to probability of risk realization:

- highly-probable;

- standard;

- improbable.

8. According to risks assessment:

- assessed by expert judgement;

- assessed through objective quantitative methods.

Islamic banking faces the similar risks as the traditional one does, excluding the risk of "non-compliance with Sharia". According to Islamic financial services Committee, there are the following risks:

- market risk (usually estimated to be higher because of a relatively small number of market players);

- investment (credit) risk (inherent in, primarily, such methods of financing as mudaraba, musharaka, ijara and others;

- liquidity risk (estimated to be higher in connection with investment into real estate assets and limited possibility of liquidity deployment).

The most common instruments, used by traditional banks for managing liquidity such as interbank credits, state and corporate bonds, are based on interest rate, and are considered as irrelevant in Sharia. Islamic financial institutions have to formulate other methods of managing liquidity.

Table 5 shows survey data on risk estimation of utilized types of financing among market players. The scale varies from 1 (less risky) to 5 (the most risky).

The leasing company is subject to influence of both common risks, characteristic of any financial and business activity, and peculiar ones, inherent in leasing transactions specifically.
TABLE 5. ISLAMIC FINANCIAL INSTRUMENTS RISKS

\begin{tabular}{|c|c|c|c|c|}
\hline Instrument & Credit & Market & Liquidity risk & Operational \\
\hline Murabah & 2.47 & 2.75 & 2.62 & 2.80 \\
\hline Mudaraba & 3.38 & 3.56 & 2.57 & 2.92 \\
\hline Musharaka & 3.71 & 3.67 & 3.00 & 3.08 \\
\hline Ijara & 2.64 & 3.17 & 3.10 & 2.90 \\
\hline Istisna & 3.13 & 2.75 & 3.00 & 3.29 \\
\hline Salam & 3.2 & 3.25 & 3.20 & 3.25 \\
\hline
\end{tabular}

In terms of common risks, the company's financial strategy can be influenced by ongoing changes in the country's economic sphere. Significant risks might appear when it is impossible to predict deterioration of financial situation of large lessees, due to negative macroeconomic changes.

Fluctuation of interest rates does not impact directly the financial and economic situation of the leasing company [15].

Leasing company's specific risks are considered financial ones and strictly related to leasing activity including legal and tax risks and also risk of a supplier's delivery contract nonfulfillment.

The most significant financial risks for leasing companies are as follows:

- risk of a reduction of effective financing sources for leasing transactions;

- risk of leasing payments non-receipt over a long period of time, including insolvency of the lessee;

- interest rate risk, which arises due to non-compliance of calculations of interest expense on borrowings obtained to finance leasing transaction and interest under the lease contract.

Within this type of risks, the following can be identified:

- risk of the schedule of issued debt securities and leasing payments non-compliance (the project's liquidity);

- risk of currency mismatch between borrowed funds and lease payments;

- risk of the low-liquid property implementation problem in the event of its return to the lessor.

Legal and tax risks, related to leasing service provision, include:

- change of currency control;

- changes of tax legislation.

In Russia, legislative and regulatory provisions are not always set clearly, and subject to interpretation by local, regional and federal tax authorities, Central Bank of the Russian Federation and the Ministry of Finance. However, there is a tight penalties and interest system, applied by tax authorities in the event of breaching Russian fiscal laws, orders and instructions: 
- changes of customs regulations and duties;

- changes of requirements on licensing of the principle activities of leasing companies or licensing the rights to use the facilities with limited availability in circulation (including natural resources);

- changes of judicial practice regarding issues related to leasing company activity (including licensing), which can negatively influence the company's performance and the results of ongoing trials which involve the companies.

Risks accompanying supply agreement are divided into two blocks:

1) risk of purchase price overrun over an average on the market, influencing the financial result if it comes to necessary implementation on the secondary market;

2) incompleteness of supplied property, late delivery, late installation or non-delivery of the lease item.

Means of minimizing the given risk groups include:

- check of history and financial state of the equipment supplier (mainly if the leasing item is manufactured to order and the timelines of advance payment and actual supply are long);

- final pay for goods and services of the supplier after proper performance of contractual obligations of the latter;

- introduction of penalties under the supply agreement.

It is anticipated that the major risks during implementation of the established company's financial strategy will be the following: financial, economic, legislative, legal and organizational.

Table 6 demonstrates estimate of the probability of their happening on a 5-point scale.

Score in points: "1" - low level of possibility, "2" possibility lower than average, "3" - average level of possibility, "4" - possibility level above average, "5" - high level of possibility.

TABLE 6. ESTIMATE OF THE PROBABILITY OF RISKS HAPPENING DURING IMPLEMENTATION OF THE LEASING COMPANY'S FINANCIAL STRATEGY

\begin{tabular}{|c|c|c|}
\hline Types of risks & Probability of risks & $\begin{array}{l}\text { Score in } \\
\text { points }\end{array}$ \\
\hline \multicolumn{3}{|c|}{ Financial risks } \\
\hline Credit and interest-rate risks & $\begin{array}{l}\text { probability below } \\
\text { average }\end{array}$ & 2 \\
\hline $\begin{array}{l}\text { Risk of non-payment by the } \\
\text { residents or their counterparts }\end{array}$ & $\begin{array}{l}\text { probability below } \\
\text { average }\end{array}$ & 2 \\
\hline \multicolumn{3}{|c|}{ Economic risks } \\
\hline Risks of inflation & $\begin{array}{l}\text { probability above } \\
\text { average }\end{array}$ & 4 \\
\hline $\begin{array}{l}\text { Risk of fiscal environment } \\
\text { deterioration (changes in system of } \\
\text { taxation) }\end{array}$ & low probability & 1 \\
\hline \multicolumn{3}{|c|}{$\begin{array}{l}\text { Regulatory and legislative risks } \\
\end{array}$} \\
\hline $\begin{array}{l}\text { Risks related to modification of the } \\
\text { legislation }\end{array}$ & $\begin{array}{l}\text { probability below } \\
\text { average }\end{array}$ & 2 \\
\hline
\end{tabular}

\begin{tabular}{|c|c|c|}
\hline $\begin{array}{l}\text { Risks related to violation of } \\
\text { legislative regulations }\end{array}$ & low probability & 1 \\
\hline \multicolumn{2}{|c|}{ Organizational risks } \\
\hline $\begin{array}{l}\text { Personnel risks (underqualification } \\
\text { of management) }\end{array}$ & low probability & 1 \\
\hline \multicolumn{2}{|c|}{ Total } & $\mathrm{x}$ \\
\hline
\end{tabular}

Assessment of consequences of risks realization towards leasing company creation project is presented in Table 7.

TABLE 7. ASSESSMENT OF CONSEQUENCES OF RISKS REALIZATION TOWARDS LEASING COMPANY CREATION PROJECT

\begin{tabular}{|c|c|c|}
\hline Types of risks & $\begin{array}{c}\text { Probability of } \\
\text { risks }\end{array}$ & Score in points \\
\hline \multicolumn{3}{|c|}{ Financial risks } \\
\hline Credit and interest-rate risks & $\begin{array}{l}\text { consequences } \\
\text { level above } \\
\text { average }\end{array}$ & 3 \\
\hline $\begin{array}{l}\text { Risk of non-payment by the } \\
\text { residents or their counterparts }\end{array}$ & $\begin{array}{l}\text { consequences } \\
\text { average level }\end{array}$ & 3 \\
\hline \multicolumn{3}{|c|}{ Economic risks } \\
\hline Risks of inflation & $\begin{array}{l}\text { consequences } \\
\text { level below } \\
\text { average }\end{array}$ & 2 \\
\hline $\begin{array}{l}\text { Risk of fiscal environment } \\
\text { deterioration (changes in } \\
\text { system of taxation) }\end{array}$ & $\begin{array}{l}\text { consequences } \\
\text { average level }\end{array}$ & 3 \\
\hline \multicolumn{3}{|c|}{ Regulatory and legislative risks } \\
\hline $\begin{array}{l}\text { Risks related to modification } \\
\text { of the legislation }\end{array}$ & $\begin{array}{l}\text { consequences } \\
\text { level below } \\
\text { average }\end{array}$ & 2 \\
\hline $\begin{array}{l}\text { Risks related to violation of } \\
\text { legislative regulations }\end{array}$ & $\begin{array}{l}\text { consequences } \\
\text { level above } \\
\text { average }\end{array}$ & 4 \\
\hline \multicolumn{3}{|c|}{ Organizational risks } \\
\hline $\begin{array}{c}\text { Personnel risks } \\
\text { (underqualification of } \\
\text { management) }\end{array}$ & $\begin{array}{l}\text { consequences } \\
\text { average level }\end{array}$ & 3 \\
\hline Total & $\mathrm{x}$ & 20 \\
\hline
\end{tabular}

Therefore, following the results of estimating the risks of Volga Region Leasing Company, implementation strategy showed that economic risks are the most probable. As for the consequences assessment, these are financial and legislative risks.

Taking into account the given above classifications of the leasing company risks and estimation, it is proposed that the methods of managing leasing company risks be introduced into management practice of a newly established company.

There are the following key demands to the system of leasing company risk management:

- building a self-reliant system providing credit risk management of the leasing company and a mechanism providing credit risks management of particular leasing projects and project portfolio;

- availability of mechanisms providing learning risks, typical for industry (or sectors), regions, leasing objects;

- availability of the system providing data support for the process of leasing projects analysis in retrospect. 


\section{CONCLUSIONS}

In the framework of the research, the authors analyzed basic methodology of development of the financial strategy for creating a leasing company under Islamic principles and the current tendencies and prospects of leasing market growth in Russia. The key aspects of the financial strategy and the major risks of implementing the financial strategy under present conditions have also been described. The efficiency of the project has been assessed.

\section{References}

[1] N.V. Onoprienko, Financial activities of the organization. Leasing, N.V. Onoprienko; monograph, Moscow State University. un-t printing. Moscow, 2009.

[2] N.I. Kravtsova, Development of financial management in the sphere of leasing relations, Bulletin of the Rostov State Economic University (RINH), № 28, pp. 189-198, 2009.

[3] E.I. Bulatova, D. Zakhmatovm, Key Developments And Trends In Project Finance Market, Academy of Strategic Management Journal, Vol.15, Is.SpecialIssue1, pp.185-190, 2016,

[4] N.N. Sokolova, T.N. Egorova, Financial strategy as the important component of the company's common strategy, Fundamental research, № 2-12, pp. 2701-2704, 2015.

[5] V.V. Litovchenko, General and special in forming the financial strategies of the enterprise, Proceedings of Tomsk Polytechnic University. Engineering of georesources, Vol. 308, № 6, pp. 190-194, 2005.

[6] A.M. Popovich, Financial strategy of the firm, Bulletin of Omsk University. Series: The Economy, № 3, pp. 61-63, 2007.
[7] E.I. Bulatova, Banking risk insurance, Banking Risks Insurance: Insurance in the Financial Services in Russia: Place, Problems, Transformation: Collection of Proceedings of the XVIIIth International Conference. scientific-practical. Conf. (Kostroma, June 7-9, 2017). In 2 vol. 1, Rosgosstrakh; Kostrom. state. un-t; otv. Ed. EV Zlobin, RT Yuldashev. - Kostroma: Publishing house Kostrom. state. Univ., 2017, pp. 212-213

[8] K. Zaretsky, Methodology for assessing the risk of a leasing project Proceedings of Tula State University. Series, Economic and legal sciences, vol. 1, pp. 34-43, 2011.

[9] G.I. Shadov, E.Yu. Drolova, The main aspects of the leasing form of financing / G.I. Shchadov, E.Yu. Drolova, Bulletin of IrSTU - 2011, No. 6 (46).

[10] O.Eremin, Development of leasing in the modern Russian economy: State industrial policy. Development of the market of services, indicators, legislative base, Industrial policy in the Russian Federation, 2016, No. 9.

[11] Rosstat [Electronic resource]: Statistics. 2017, Official site of Rosstat, 2017, Access mode: www.gks.ru

[12] Rating Agency "Expert RA" [Electronic resource]: The leasing market. Scenarios of development until 2020, Official site of the Rating Agency "Expert RA",Access mode: http://raexpert.ru

[13] V. Gazman Leasing in the legislation: problems and judgments. Development of leasing legal relations in Russia. Characteristic of the main stages, Leasing revue, 2011, No. 6.

[14] E.V. Beregatnova, Leasing market of the Russian Federation: state, prospects - 2016, National Research University Higher School of Economics, https: //dcenter.hse.ru.pdf

[15] M.V. Malafeeva, Leasing as a financial instrument of investment, The dissertation author's abstract on competition of a scientific degree of the candidate of economic sciences, Ivanovo state chemical-technological university. Ivanovo, 2003. 